Laporan Penelitian

\title{
Pewarnaan Toluidin blue sebagai petanda ketepatan biopsi pasca terapi karsinoma sel skuamosa kepala-leher
}

\author{
Bambang Hariwiyanto, Camelia Herdini, Inawati Bobot \\ Bagian Ilmu Kesehatan Telinga Hidung Tenggorok \\ Fakultas Kedokteran Universitas Gajah Mada/Rumah Sakit Umum Pusat Dr Sardjito Yogyakarta.
}

\begin{abstract}
ABSTRAK
Latar belakang: Karsinoma sel skuamosa (KSS) merupakan jenis keganasan kepala dan leher yang paling sering dijumpai dibanding keganasan yang lain. KSS kepala leher dapat dilakukan terapi pembedahan diikuti kemoterapi dan/atau radioterapi maupun kemoterapi dan/atau radioterapi tanpa pembedahan. Penentuan keberhasilan radikalitas pengobatan ditandai dengan tidak adanya sisa tumor secara mikroskopis yang diambil pada jaringan pasca kemoradiasi tanpa pembedahan, atau pemeriksaan jaringan secara frozen section. Untuk menentukan apakah pada jaringan masih ada sisa tumor atau sudah bebas tumor secara makroskopis terkadang sulit. Toluidin Blue (TB) adalah zat pewarna yang dapat terserap pada ruang interseluler epitel yang mengalami displasia seperti yang terjadi pada KSS. Tujuan: Menilai validitas pewarnaan TB sebagai petanda ketepatan lokasi biopsi KSS pasca terapi, baik pasca pembedahan, maupun yang diterapi dengan kemoterapi dan/atau radioterapi tanpa pembedahan. Metode: Uji diagnostik untuk menentukan sensitifitas dan spesifitas pewarnaan, nilai duga positif dan nilai duga negatif TB sebagai salah satu petanda ketepatan biopsi KSS pasca terapi KSS kepala-leher. Hasil: Didapatkan 30 sampel penelitian yang berasal dari 26 penderita KSS yang telah dilakukan terapi baik bedah maupun kemoradiasi tanpa bedah. Sensitifitas pewarnaan TB terhadap hasil biopsi pasca terapi $83,3 \%$, spesifitas $66,7 \%$, nilai duga positif $79,0 \%$ dan nilai duga negatif $72,7 \%$. Kesimpulan: Pewarnaan TB valid untuk menentukan ketepatan biopsi keganasan KSS kepala dan leher pasca terapi.
\end{abstract}

Kata kunci: Validitas, toluidin blue, karsinoma sel skuamosa, pasca terapi

\section{ABSTRACT}

Background: Squamous cell carcinoma (SCC) is the most frequent malignancy in the head and neck. The treatment modalities of SCC are surgery followed by chemotherapy and/or radiotherapy, could also chemotherapy and/or radiotherapy without surgery. The gold standard of assessing success in SCC treatment is if there no malignant cells found not only in frozen section tissues, but also in post chemotherapy and/or radiotherapy tissues. Determining the spot of biopsy tissue for malignancy assessment after treatment is not easy. Toluidin Blue (TB) is a staining material, absorbed by intercellular space in epithelial dysplasia, included SCC.

To determine the validity of Toluidin Blue as sign of accuracy for biopsy site in SCC post treatment malignancy, which not only for surgically treated cases, but also after chemotherapy and/or radiotherapy without surgical treatment. Method: Diagnostic test study to determine sensitivity test, specificity test, positive predictive value and negative predictive value of TB to detect malignant cells in post treatment head and neck SCC patients. Result: There were 30 samples biopsy material from 30 post treatment SCC patients. Sensitivity test was $83,3 \%$, specificity test: $66,7 \%$, positive predictive value: $79.0 \%$, negative predictive value: $72,7 \%$. Conclusion: TB staining is accurate for determining biopsy spot in post treatment head and neck SCC.

Keyword : Validity, toluidin blue, squamous cell carcinoma, post treatment. 


\section{PENDAHULUAN}

Karsinoma sel skuamosa (KSS) merupakan jenis tumor ganas yang paling sering terjadi diantara tumor ganas lain yang terdapat pada kepala leher. ${ }^{1,2}$ Salah satu tolak ukur keberhasilan pengangkatan tumor (pembedahan) secara radikal, ditunjukan dengan tidak adanya sisa tumor secara mikroskopis selama pembedahan, yang sampai saat ini menggunakan pemeriksaan secara frozen section. Pada KSS kepala dan leher yang tidak dapat dilakukan pembedahan, seperti pada karsinoma nasofaring (KNF) keberhasilan terapi ditunjukan dengan hasil biopsi pasca kemoterapi dan/atau radioterapi. Ketepatan daerah yang akan dilakukan biopsi baik untuk keperluan frozen section maupun untuk penentuan keberhasilan terapi terkadang sulit, sehingga mengakibatkan hasil yang tidak tepat. Di beberapa rumah sakit untuk pemeriksaan frozen section diperlukan tambahan biaya dan waktu pemeriksaan yang tidak sedikit, sedangkan biopsi nasofaring merupakan tindakan invasive yang menyakitkan bagi penderita KNF.

Toluidin Blue (TB) adalah zat pewarna thiamine metachromatic dengan berat molekul 305, dan larut dalam air dan alkohol., ${ }^{3,4}$ Merupakan bahan acidophilic yang secara selektif dapat mewarnai komponen asam nukleat DNA dan RNA sel, dengan cara berikatan dengan kelompok thiazine seperti sulfat, fosfat dan radikal karboksilat dari asam amino. Ikatan TB ini menyebabkan TB dapat terserap pada ruang interseluler epitel yang mengalami displasia. Pada keganasan epitel, TB dapat diserap oleh karena pada keganasan epitel lebih banyak mengandung asam nukleat. ${ }^{5,6}$

Pewarnaan TB untuk mendeteksi adanya keganasan pada mukosa, terutama pada epitel orofaring sudah digunakan sejak berpuluh tahun yang lalu. ${ }^{3,7}$ Hal ini disebabkan karena TB mempunyai kemampuan untuk berikatan dengan kelompok fosfat pada asam nukleat dan dapat terserap pada ruang interseluler epitel yang mengalami displasia. TB dapat terserap pada epitel yang mengalami displasia dan malignansi karena tidak adanya gen supresor tumor dan jumlah asam nukleat jauh lebih banyak dibandingkan dengan epitel normal, selain itu pada epitel maligna terdapat ruang interseluler yang lebih lebar..$^{5,6,7}$

TB cenderung mewarnai jaringan yang mengandung komponen rantai kimia asam yang banyak terdapat pada jaringan atau sel yang tidak terkontrol proliferasinya. ${ }^{8}$ Ketidakmampuan sel sehat menyerap TB disebabkan karena sel sehat mempunyai pertahanan yang efektif berupa permeabilitas yang selektif. Sel normal bersifat lipolitik, sedangkan TB bersifat hidrofobik, sedangkan jaringan keratosis tidak dapat menyerap TB karena lapisan permukaannya tertutup oleh jaringan keratin., ${ }^{4,6}$

Penelitian ini bertujuan untuk mengetahui validitas pewarnaan TB sebagai salah satu petanda ketepatan biopsi penderita KSS kepala leher pasca terapi. baik yang diterapi secara pembedahan maupun yang diterapi dengan kemoterapi dan/ atau radioterapi tanpa pembedahan.

\section{METODE}

Desain penelitian ini adalah uji diagnostik untuk menentukan sensitifitas dan spesifitas pewarnaan TB sebagai salah satu petanda ketepatan biopsi penderita KSS kepala leher. pasca terapi pembedahan atau kemoterapi dan/ atau radio terapi tanpa pembedahan. Sampel penelitian berupa jaringan biopsi frozen section yang ditujukan untuk mengetahui radikalitas operasi dan biopsi tumor primer KSS pada 12 minggu pasca kemoterapi dan/atau radioterapi tanpa pembedahan..

Jaringan yang dicurigai masih mengandung sisa tumor selama pembedahan untuk keperluan frozen section atau pasca kemoterapi dan/ atau radioterapi yang akan dibiopsi, dilakukan pengolesan dengan menggunakan kapas lidi yang sudah dibasahi dengan TB 1\%, ditunggu selama 1 menit kemudian dibilas dengan garam fisiologis yang bertujuan untuk menghilangkan TB yang larut pada jaringan normal. Biopsi dilakukan pada daerah yang sudah diolesi dengan TB $1 \%$, baik yang masih berwarna 
Tabel 1: Tabel 2X2 untuk perhitungan sensitifitas dan spesifitas

\begin{tabular}{llccc}
\hline \multirow{4}{*}{ Pewarnaan TB } & \multicolumn{3}{c}{ Biopsi pasca terapi } \\
\cline { 2 - 5 } & Positif & Positif & Negatif & Total \\
& Negatif & (a) & (b) \\
& Total & (c) & (d) & \\
\hline
\end{tabular}

Tabel 2: Karakteristik subjek penelitian

\begin{tabular}{llrr}
\hline & \multicolumn{1}{c}{ Variabel } & N & $(\%)$ \\
\hline Jenis kelamin & Laki laki & 21 & $80,76 \%$ \\
& Perempuan & 5 & $19,24 \%$ \\
Umur & $>50$ thn & 15 & $57,69 \%$ \\
& $<50$ thn & 11 & $42,31 \%$ \\
Letak tumor & Laring (total laringektomi) & 3 & $10,00 \%$ \\
(jenis operasi) & Leher (deseksi leher) & 7 & $23,33 \%$ \\
& Nasofaring (pasca terapi) & 10 & $33,33 \%$ \\
& Parotis (Parotidektomi) & 2 & $6,66 \%$ \\
& Hidung/SPN (ektirpasi) & 7 & $23,33 \%$ \\
& Telinga (ektirpasi tumor) & 1 & $3,33 \%$ \\
\hline
\end{tabular}

Tabel 3: Hasil pewarnaan TB dan biopsi

\begin{tabular}{|c|c|c|c|c|}
\hline \multirow{5}{*}{ Pewarnaan TB } & & \multicolumn{3}{|c|}{ Biopsi pasca operasi } \\
\hline & & Positif & Negatif & Total \\
\hline & Positif & $15(50,00 \%)$ & $4(13,33 \%)$ & $19(63,33 \%)$ \\
\hline & Negatif & $3(10,00 \%)$ & $8(26,67 \%)$ & $11(33,67 \%)$ \\
\hline & Total & $18(60,00 \%)$ & $12(40,0 \%)$ & $30(100,00 \%)$ \\
\hline
\end{tabular}

biru tua (positif) maupun biru muda atau tidak berwarna biru (negatif). ${ }^{9}$ Jaringan biopsi diperiksa di Bagian Patologi Anatomi RSUP DR Sardjito. Penelitian ini dilakukan terhadap penderita KSS yang berobat di Bagian THT RSUP DR Sardjito dan dilakukan pembedahan maupun kemoterapi dan/atau radioterapi tanpa pembedahan, yang memenuhi kriteria inklusi dan eksklusi selama bulan Desember 2010 s/d Desember 2011.

Hasil penelitian dipresentasikan dalam tabel 2 $\mathrm{X} 2$ untuk perhitungan sensitifitas, spesifitas, nilai duga positif dan nilai duga negatif pewarnaan TB sebagai petanda ketepatan biopsi. (Tabel 1)

Sensitifitas: $a /(a+c)$ X 100\%, Spesifitas: $d /$ $(d+b) X 100 \%$. Nilai duga positif: $a /(a+b) X$ $100 \%$. Nilai duga negatif: $d /(c+d) X 100 \%$.

\section{HASIL}

Didapatkan 30 sampel biopsi KSS, baik untuk keperluan frozen section, maupun biopsi 12 minggu pasca kemoterapi dan/atau radioterapi tanpa pembedahan yang berasal dari 26 penderita KSS. Karakteristik sampel dapat dilihat pada tabel 2.

Hasil perbandingan antara pewarnaan TB dengan hasil pemeriksaan Patologi Anatomi dapat dilihat pada tabel 3 . 
Kemampuan pewarnaan TB dalam memberikan hasil uji positif pada pasca terapi pembedahan maupun kemoterapi dan/atau radioterapi tanpa pembedahan ditunjukan dengan hasil uji sensitifitas: $15 / 18$ X 100\% $=83,3 \%$. Hasil tersebut menunjukan bahwa apabila hasil biopsi menunjukan adanya tumor, $83,3 \%$ nya dapat ditunjukan dengan warna biru tua pada jaringan pasca pewarnaan dengan TB 1\%. Kemampuan hasil pewarnaan TB dalam memberikan uji negatif pasca pembedahan maupun kemoterapi dan/radioterapi tanpa pembedahan ditunjukan dengan uji spesifitas: $8 / 12$ X 100\% $=66,7 \%$. Hasil tersebut mengandung makna bahwa bila hasil biopsi menunjukan tidak ada tumor, $66,7 \%$ nya dapat ditunjukan dengan tidak ada jaringan yang berwarna biru tua pasca pewarnaan TB $1 \%$.

Besarnya kemungkinan bahwa daerah yang berwarna biru tua benar-benar didapatkan sisa tumor ditunjukan dengan nilai duga positif: $15 / 19 \times 100 \%=79,0 \%$, sedangkan besarnya Gbahw?

biru tua benar-benar tidak mengandung sisa tumor ditunjukan dengan nilai duga negatif: 8/11 X $100 \%=72,7 \%$.

\section{DISKUSI}

Berdasarkan karakteristik subjek penelitian didapatkan data yang tidak menyimpang dari data yang diperoleh dari beberapa kepustakaan yang menerangkan bahwa diantara tumor kepala leher laki laki lebih banyak dibanding perempuan, letak tumor paling banyak adalah nasofaring, diikuti oleh hidung/sinus paranasal. ${ }^{2}$

Adanya hasil positif palsu kemungkinan disebabkan karena pembilasan pasca pewarnaan kurang sempurna. Hal ini disesuai dengan penelitian Onofre et $a l^{8}$ yang mengatakan bahwa mitokondria sel normal dapat juga menyerap TB, tetapi penyerapannya lemah dan pembilasannya perlu waktu lebih lama. Adanya negatif palsu disebabkan karena adanya jaringan biopsi yang rusak karena hemostat, atau kauter, sehingga tidak dapat menyerap TB dengan baik, serta adanya perdarahan pada daerah yang akan dibiopsi.
Hasil penelitian ini berbeda dengan penelitian Allegra et $a l^{10}$ dari penelitian TB sebagai alat diagnosis KSS orofaring yang mendapatkan hasil: sensitifitas $96,2 \%$ dan spesifitasnya $77.7 \%$. Hal ini kemungkinan disebabkan karena pewarnaan TB pada orofaring yang dilakukan oleh Allegra dengan cara berkumur selama beberapa menit, sedangkan pada penelitian ini pewarnaan TB dengan cara dioleskan menggunakan kapas lidi selama 1 menit, sehingga penyerapan TB kurang optimal. Hasil penelitian ini tidak jauh berbeda dengan hasil penelitian Bobot $\mathrm{dkk}^{9}$ yang melakukan penelitian validitas pewarnaan TB sebagai petanda KSS nasofaring didapatkan hasil: sensitifitas $86 \%$, spesifitas $67 \%$. Adanya sedikit perbedaan tersebut kemungkinan karena subyek penelitian pada penelitian Bobot $\mathrm{dkk}^{9}$ hanya terbatas pada karsinoma nasofaring yang belum diterapi, sedangkan pada penelitian ini subyek penelitian adalah semua karsinoma pada kepala dan leher yang sudah dilakukan terapi.

Berdasarkan hasil penelitian ini dapat disimpulkan bahwa pewarnaan TB dapat digunakan sebagai salah satu alternatif menentukan ketepatan lokasi jaringan yang akan dilakukan biopsi baik pada penderita KSS selama pembedahan untuk keperluan frozen section, atau KSS yang sudah dilakukan kemoterapi dan/atau radioterapi tanpa pembedahan untuk keprluan penentuan keberhasilan terapi. Disarankan dilakukan penelitian validitas pewarnaan TB terhadap masing masing KSS kepala leher.

\section{DAFTAR PUSTAKA}

1. Chao SS, Loh KS, Tan LKS. Modalities of surveillance in treated nasopharyngeal cancer. Otolaryngol Head and Neck Cancer 2003; 129:61-4.

2. Islami H, Bobot A, Budi A, Bawono M, Hariwiyanto B. Karakteristik keganasan kepala leher di RSUP Dr Sardjito. KONAS PERHATI XV Makassar 2010.

3. Zhang L, William M, Poh CF, Laronde D, Epstein JB, Durham S, et al. Toluidin blue staining identifies high risk primary oral premalignant lesion with poor outcome. Cancer Res 2005; 1:25-30.

4. Guneri P, Epstein JB, Kaya A, Veral A, Kazandi A, 
Boyacioglu H. The utility of toluidin blue staining and brush cytology as adjunct in clinical examination of suspicious oral mucosal lesion. Int. J.Oral Maxillofac Surg 2010; 30:30-2.

5. Hedge MC, Kammath PM, Shreedharan S, Dannana NK, Raju RM. Supravital staining: its role in the detecting early malignancies. Indian J Otolaryngol Head Neck Surg 2006; 58:12- 5.

6. Epstein JB, Guneri P. The adjunctive role of toluidine blue in detection of oral premalignant and malignant lesion. Current Opinion. Otolaryngol Head Neck Surg 2009; 17:79-87.

7. Patton LL, Epstein JB, Kerr AR. Adjunctive techniques for oral cancer examination and lesion diagnosis: a systematic review of the literature. J Am Dent Assoc 2008; 139:896-905.
8. Onofre MA, Sposto MR, Navaro MC. Reliability of toluidin blue application in the detection of oral epithel dysplasia and insitu and invasive squamous cell carcinoma. Oral Surg Oral Path 2001; 91:535-40.

9. Bobot I, Herdini C, Hariwiyanto B. Validitas pewarnaan toulidin blue sebagai petanda karsinoma sel skuamosa nasofaring. Karya Tulis Akhir. Bagian Ilmu Kesehatan Telinga Hidung dan Tenggorok. Fakultas Kedokteran UGM 2012.

10. Allegra E, Lumbardo N, Puzzo L, Garrozo A. The usefulness of toludin blue staining as diagnostic tool for precancerous and cancerous oropharyngeal and oral cavity lesion. Acta Otolaryngol 2009; 29:187-90. 